\title{
Fabrication and Characterization of Woven and Non- woven Textiles Derived from Natural Resources
}

\author{
Siti Nikmatin 1,2,", Irmansyah Irmansyah ${ }^{1}$, Mohammad Nur Indro ${ }^{1}$, Mulia Hendra ${ }^{1}$, Tony Setiawan ${ }^{3}$, \\ Achmad Syafiuddin 4,* (D) \\ 1 Department of Physics, IPB University (Bogor Agricultural University), 16680 Bogor, West Java, Indonesia \\ 2 Surfactant and Bioenergy Research Center (SBRC), IPB University (Bogor Agricultural University), 16680 Bogor, West \\ Java, Indonesia \\ 3 Center of textiles, 40272 Bandung, West Java, Indonesia \\ 4 Department of Public Health, Universitas Nahdlatul Ulama Surabaya, 60237 Surabaya, East Java, Indonesia \\ * Correspondence: snikmatin@apps.ipb.ac.id (S.N.); achmadsyafiuddin@unusa.ac.id (A.S.);
}

Scopus Author ID 56515330600; 56682128000

Received: 8.04.2021; Revised: 8.05.2021; Accepted: 15.05.2021; Published: 10.06.2021

\begin{abstract}
The present work investigated the properties of long fibers derived from oil palm empty fruit bunches (OPEFB) for the potential woven and non-woven textiles production. Several characterizations such as XRD, FTIR, SEM-EDX, DSC, and mechanical testing were carried out to understand the properties comprehensively. This study found that the OPEFB has the potential for the production of woven and non-woven textiles. The properties of OPEFB fibers were comparable with synthetics fibers that are commonly used in the textile industry. XRD analysis confirmed the structural properties, while the FTIR showed the biomolecules' bonding characteristics. In general, the physical and mechanical properties of the OPEFB fibers depend on surface modification and chemical treatments.
\end{abstract}

Keywords: Oil palm empty bunches; natural fibers; mechanical properties.

(C) 2021 by the authors. This article is an open-access article distributed under the terms and conditions of the Creative Commons Attribution (CC BY) license (https://creativecommons.org/licenses/by/4.0/).

\section{Introduction}

The effort to increase the number and variety of textile products, especially the organic raw material for woven fabrics, which is sourced from waste utilization, is an innovation in increasing the diversity of organic non-cotton textile raw materials and solving the national palm oil solid waste problem into high economic products [1-4]. Oil palm empty fruit bunches (OPEFB) are solid waste from palm oil production, produced into long fibers by chemicalphysical extraction methods [5-7]. Surface modification of the resulting long fibers can produce organic fibers with mechanical properties similar to synthetic fibers for the textile industry $[8,9]$.

The extent of oil palm plantations in Indonesia can meet the national need for vegetable oil and its derivatives as well as export fulfillment. The problems in palm oil production are the production of solid waste and the release of liquid waste Palm Oil Mill Effluent (POME) that should be given special attention [10-12]. Utilization of OPEFB with technology and producing organic fiber products that can be woven (woven and non-woven) in order to increase economic value has a strategic role in the development and supply of national textiles $[13,14]$. This strategy can be realized through real contributions in producing applicable material engineering for palm oil products and diversifying competitive textiles. 
This study analyzes the behaviors of long fibers derived from OPEFB for the potential woven and non-woven textiles production. Several characterizations such as XRD, FTIR, SEM-EDX, DSC, and mechanical testing were carried out. Findings from this study exhibited that the OPEFB can potentially produce woven and non-woven textiles. The properties of OPEFB fibers were comparable with synthetics fibers that are commonly used in the textile industry.

\section{Materials and Methods}

\subsection{Materials.}

The main material used in this study is OPEFB obtained from from PTPN VIII Cikasungka, Bogor Regency. Long fiber was synthesized in the Manunggal Alam UKM, Wirajaya Jasinga, Bogor, West Java. Non-woven fabrics were manufactured at Center for textiles, Bandung. Woven fabrics were made at UKM Bintang Terang Putra Majalaya, Bandung.

\subsection{Alkaline peroxide treatment.}

The alkaline peroxide treatment was carried out in accordance with the previous works. Briefly, OPEFB fibers are mixed with $0.4 \%$ sodium hydroxide solution. The mixture was heated at $60^{\circ} \mathrm{C}$ in a water bath and stirred at $200 \mathrm{rpm}$ for 1 hour. Then, the mixture was filtered and washed with distilled water. Further, the solid residue is mixed with $4 \%$ hydrogen peroxide solution. $50 \%$ sodium hydroxide is added to the suspension until the $\mathrm{pH}$ of the suspension reaches 11.5. The suspension was then heated at $80{ }^{\circ} \mathrm{C}$ at different reaction times, which are 30, 90, 180, and $360 \mathrm{~min}$. Then, the suspension was filtered and the residue was washed to a neutral $\mathrm{pH}$. The size of the long fiber is measured based on the IAWA (International Association of Wood Anatomy) standardization with the average dimensions of the fibers measured using an optical microscope.

\subsection{OPEFB fiber surface modification.}

OPEFB fiber surface modification was carried out by immersion variations with a sunsoft solution at a concentration ranging from $2-10 \% \mathrm{w} / \mathrm{w}$ and time variation ranging from 6-14 $\mathrm{h}$ at room temperature. Then, the modified OPEFB fibers were dried under the sun until the moisture content reached $20 \%$. After drying, the fiber samples were put in a drying oven at $100{ }^{\circ} \mathrm{C}$ for $8 \mathrm{~h}$ until the moisture content was less than $7 \%$. The resulting soft OPEFB fibers are then subjected to a mechanical process with a spinning machine to unite or twist the OPEFB fibers into a surface-smooth strand followed by a homogeneous diameter. Woven fibers are made using ATBM woven webbing and non-wovens are made using sewing equipment.

\subsection{Characterization.}

Testing the quality of OPEFB fiber is carried out with a chemical composition based on the standards of the Pulp and Paper Industry Technical Association (TAPPI). The density was carried out using the Archimedes method. Thermal testing was carried out in accordance with SNI 08-1512-89 vertical test textile standards. Several characterizations were carried out to determine the properties of samples, such as by using XRD, FTIR, SEM-EDX, DSC, and ASTM. In the preparation, the OPEFB woven fibers were cut to $40 \mathrm{x} 40 \mathrm{~cm}$ and immersed in 
ATH solution with various concentrations of $15 \mathrm{phf}, 30 \mathrm{phf}$, and $60 \mathrm{phf}$. Furthermore, the OPEFB woven fibers were immersed in ATH and oven for $2 \mathrm{~h}$ at $100{ }^{\circ} \mathrm{C}$. Furthermore, the sample was subjected to a burn test using SNI Textile standardization with 5 repetitions for each concentration. In addition, mechanical tests were also carried out to determine the effect of increasing the concentration of ATH on the mechanical properties of the fibers to be used as a filler in composites.

\section{Results and Discussion}

\subsection{XRD analysis.}

The optimum value for used fiber as a material for making woven and non-woven fabrics is based on variations in concentration and dyeing during the extraction process at room temperature (Figure 1). The best results were based on testing the chemical composition of OPEFB with TAPPI standards, namely the resulting cellulose content of $55.08 \%, 25.06 \%$ for hemicellulose, $19.14 \%$ for lignin, $5.24 \%$ for extractive substances, $5.97 \%$ for water content, $3 \%$ for fat content and $80.14 \%$ for holocellulose [15].
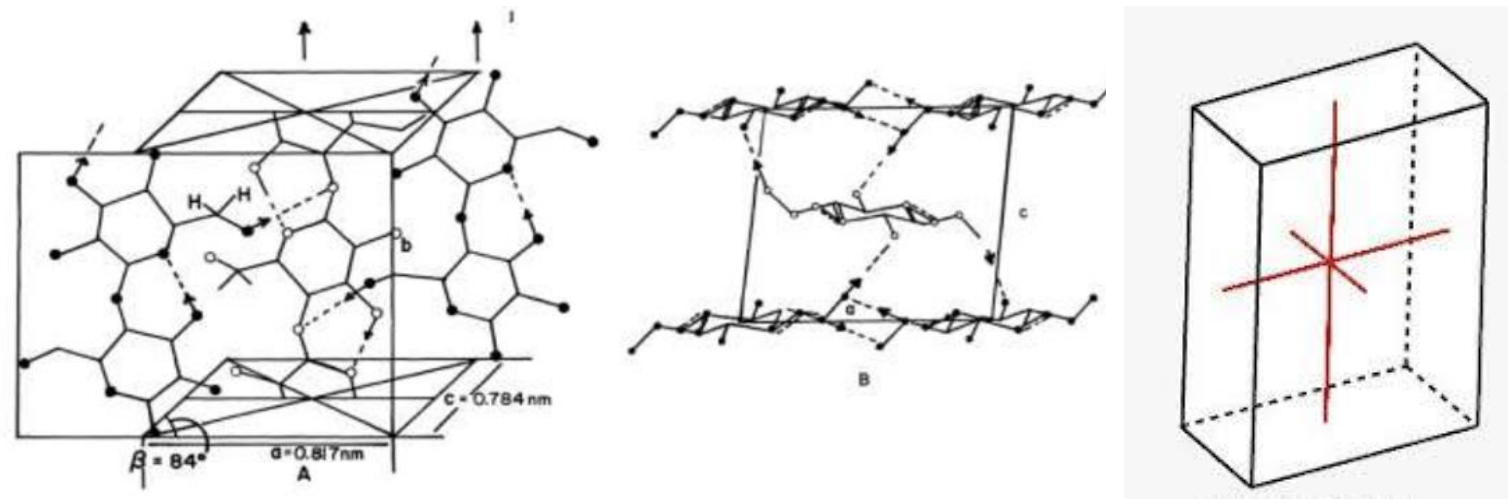

Figure 1. Monoclinic structure of cellulose unit cells.

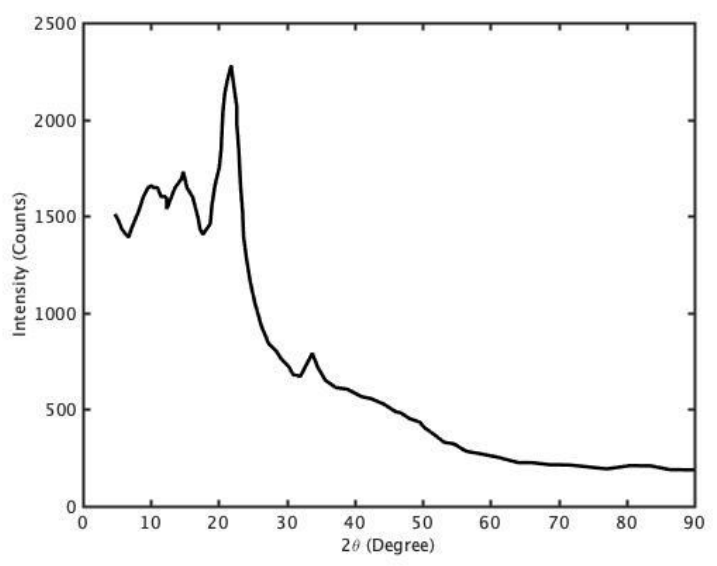

Figure 2. OPEFB fiber XRD profile.

OPEFB fiber microstructure was examined using an XRD instrument to analyze crystallinity, Miller's index, and phase structure [16,17]. Figure 1 and Figure 2 show that the OPEFB used fibers have a monoclinic phase structure with $\mathrm{a} \neq \mathrm{b} \neq \mathrm{c}$ and $\alpha=\gamma=900 \neq \beta$ with a crystal peak angle at $2 \theta=22^{\circ}$ at hkl 002 [18]. Some peaks look amorphous at $2 \theta=35-80$ degrees. Indexing of the diffraction profile was performed using powder- $\mathrm{X}$ that result in lattice 
parameters $a=7.87, b=10.31, c=10.13$ and $a=g=90, b=120$. In the crystalline region of cellulose, each atom occupies a regular position in the lattice periodically and it is repeated until a solid structure is formed based on its crystallography. The higher the crystallinity of cellulose, the stronger the properties of the bio composite-forming material against deformation [19]. Meanwhile, in the amorphous region, there is no visible peak, where the atoms making up the OPEFB fibers are not at the lattice point, therefore, they are not brave. It reflects that the method has not made OPEFB fibers with high cellulose purity with a high degree of crystallinity. The energy generated during the production process has not been able to penetrate the cell walls optimally.3.2. FTIR analysis.

Molecular groups in OPEFB fibers were tested using FTIR. It was assessed to obtain information on the role of OPEFB fibers in binding with other materials together in the molecular building of composite structures. Figure 3 shows the FTIR image of the OPEFB fiber sample. The transmittance peak of the FTIR spectra reflects chemical functional groups. The peak seen at wave number $3700-3200 \mathrm{~cm}^{-1}$ shows the $\mathrm{O}-\mathrm{H}$ stretching of the cellulose hydroxyl groups. The absorbance peak at $3300-3450 \mathrm{~cm}^{-1}$ indicates the presence of $\mathrm{O}-\mathrm{H}$ stretching of the cellulose hydroxyl groups [20,21]. The transmittance of the wavenumbers $3333 \mathrm{~cm}^{-1}$ to 3348 and $3379 \mathrm{~cm}^{-1}$ are intra-and intermolecular hydrogen bonds. 3000 and 2800 $\mathrm{cm}^{-1}$ are aliphatic saturation $\mathrm{C}-\mathrm{H}$ stretching vibrations [22]. Kubovský, Kačíková [23] explained that the occurrence of a bond between $3300-3600 \mathrm{~cm}^{-1}$ is the stretching of lignin (intramolecular hydrogen bond in phenolic groups, $\mathrm{OH}$ stretching of alcohols, phenols, acids and weakly bounded absorbed water). Lignin also had bands about $2900 \mathrm{~cm}^{-1}(\mathrm{C}-\mathrm{H}$ stretching in methyl and methylene groups).

As shown in Figure 3, it can be seen that the wavenumber 1605 to $1589 \mathrm{~cm}^{-1}$ is $\mathrm{C}=\mathrm{C}$ stretching vibration and stretching symmetric of lignin. The peaks of 1450 and $1435 \mathrm{~cm}^{-1}$ indicate $\mathrm{O}-\mathrm{H}$ and symmetric $\mathrm{CH}_{2}$ at $\mathrm{C}_{6}$ of cellulose [24]. The transmittance peak at $1250 \mathrm{~cm}^{-}$ ${ }^{1}$ is $\mathrm{C}-\mathrm{O}$ stretching aryl alkyl ether lignin. Carboxylic acid groups and tertiary amides can be found in the wavenumbers 1260 to $1240 \mathrm{~cm}^{-1}$. A peak at $1049 \mathrm{~cm}^{-1}$ indicates the presence of silica groups $\mathrm{Si}-\mathrm{O}-\mathrm{Si}$ and $\mathrm{SiO}-\mathrm{H}$. The OPEFB fiber sample shows a peak at wave number $663 \mathrm{~cm}^{-1}$ is $\mathrm{COH}$.

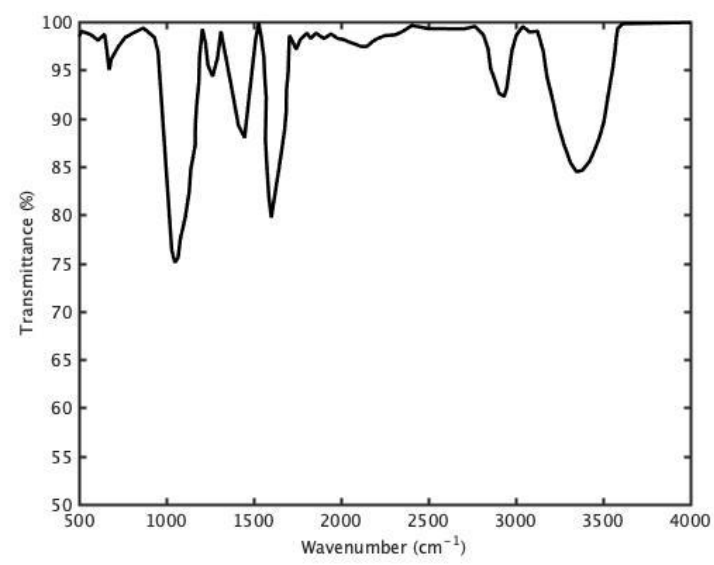

Figure 3. FTIR spectra of OPEFB fibers.

\subsection{Surface morphology and thermal properties.}

Micro morphology was assessed using an optical microscope (MO) and scanning electron microscope (SEM) instruments to analyze changes in the surface of OPEFB fibers 
during the treatment process. Figure 4 shows that the extracted OPEFB fibers have a waxy layer, have pores, trachea and a rough surface.

Thermal testing with DSC aims to determine the response of OPEFB fibers to heat which includes endothermic, exothermic, glass transition and melting points, which will be correlated with a flame test. The OPEFB fiber material in the endothermic phase $(\Delta \mathrm{H}=128 \mathrm{~J}$ $\left.\mathrm{g}^{-1}\right)$ is the first phase when the material absorbs heat for water evaporation until the initial temperature of $48{ }^{\circ} \mathrm{C}$ to $79{ }^{\circ} \mathrm{C}$ [20]. Then, the glass transition phase occurs when the material is in rubber formation $121{ }^{\circ} \mathrm{C}$ and melts at $270{ }^{\circ} \mathrm{C}$. When the material receives a heat response, the next step is the exothermic phase $\left(\Delta \mathrm{H}=32.8 \mathrm{~J} \mathrm{~g}^{-1}\right)$ at $307{ }^{\circ} \mathrm{C}$. The next stage is carbonization. The areas under the endothermic and exothermic curves show the change in enthalpy $(\Delta \mathrm{H})$, which is the energy required to change the thermal phase of the material (Figure $5)$.

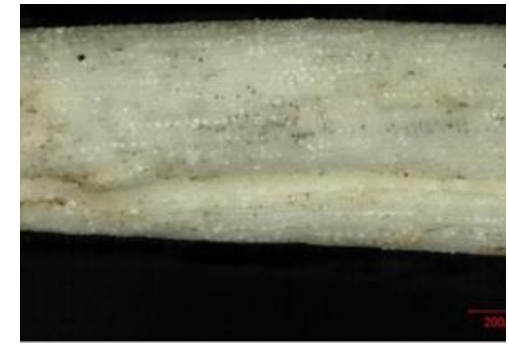

(a)

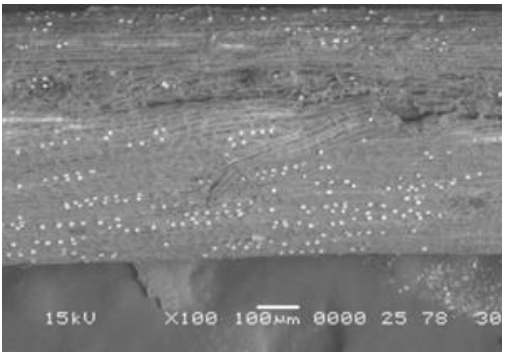

(b)

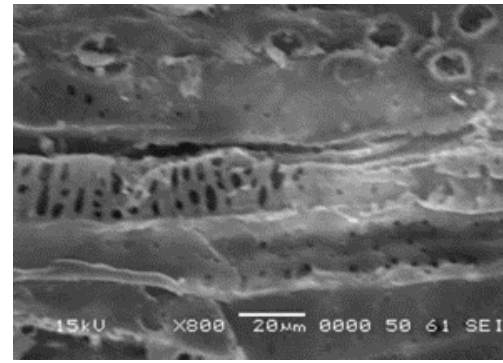

(c)

Figure 4. OPEFB fiber morphology by means of (a) MO; (b) SEM 100x; (c) SEM 800x.

\subsection{Mechanical properties.}

To determine the external deformation ability of the material, tensile strength (TS) testing on single OPEFB and woven fibers was carried out using ASTM D638 with 5 repetitions. Based on Table 1, it can be explained that the TS bundle fiber has an average value of $30.99 \mathrm{MPa}$. Meanwhile, the TS of EFB fiber in the form of yarn as raw material for woven is $80 \mathrm{MPa}$. The OPEFB fiber bundle obtained from the treatment process has a high tensile strength when two opposing vertical forces are applied during the test. Compared with woven OPEFB fibers arranged from bundles of bundles with spun physical bonds between the fibers to form yarn, the arrangement of OPEFB fibers into webbing has a higher mechanical strength. This is because the tensile strength test, the breaking strength when given the opposite vertical tensile force at the base and tip of the sample per unit area, is calculated based on the breaking of the fibers and the bonds between the fibers on the woven very strong. Testing mechanical properties in automotive component applications emphasized a single fiber. TKSS fibers have a role in spreading the accepted deformation along the fibers in the polymer matrix without breaking. Therefore, information regarding tensile strength is needed. Meanwhile, bullet-proof materials require information on the ability of OPEFB fibers in the form of woven threads (a collection of several fiber bundles) to inhibit or absorb kinetic energy after the collision. Furthermore, the bullet can become lodged in the material, or the bullet has an unresponsive impact after the impact.

Mechanical analysis of tensile test on woven OPEFB fibers was carried out to determine the tensile strength of the fibers [25]. The analysis is needed to determine the feasibility of fibers as a filler material in composites. This test was carried out on woven fiber samples with 
variations in the concentration of ATH, namely $15 \mathrm{phf}$ (TK-1), $30 \mathrm{phf}$ (TK-2), $60 \mathrm{phf}$ (TK-3) with 3 repetitions of each. The tensile test that follows ASTM D638 is a test by carrying out the pull/stretching of a test rod that continuously increases due to the load acting on the test rod until the test rod breaks. The measurement process is carried out using a Computer Control Electronic Universal Testing Machine with a displacement speed of $50 \mathrm{~mm} \mathrm{~min}^{-1}$. The gauge length of the sample is $50 \mathrm{~mm}$. Several parameters are used to analyze mechanical properties, such as tensile strength, elongation at break, and Young's modulus.

Tensile strength is defined as the maximum tensile (stress) that can be achieved by the specimen when the specimen breaks/tears. Based on the tensile test results on each sample, it is known that the tensile strength increases with increasing concentration. At the highest ATH concentration (60 phf), the highest tensile strength was obtained at 476.61 MPa. Furthermore, for the ATH concentration of $15 \mathrm{phf}$ and $30 \mathrm{phf}$ the tensile strength values were $374.33 \mathrm{MPa}$ and $424.8 \mathrm{MPa}$, respectively. A number of studies have stated that adding a flame retardant, for example, ATH, to a specimen will generally reduce mechanical properties. However, other researchers stated that the addition of ATH concentration at a certain concentration actually increases the tensile strength value. It is caused by ATH inhibits the mobility of the matrix used. The flame retardant (FR) in a specimen acts as a nucleating agent that can reduce tensile strength and reduce elongation at break, except in specimens with lower FR concentrations. However, it indicated that the ATH concentration used in this study was still relatively low. The high ATH concentration did not decrease the tensile strength of the sample.

Elongation at break is the increase in the length of a test piece when it is stretched until it breaks, expressed as a percent (\%) of the length of the test piece before being stretched [26]. The test is carried out in order to determine the stress and strain properties of the specimen. Based on the results of the tensile test, it is known that the percentage of elongation at break increases with an increase in concentration. At $15 \mathrm{phf}$ and $30 \mathrm{phf}$ ATH concentrations, it is known that the elongation at break value is $0.18 \%$. Then at the ATH concentration of $60 \mathrm{phf}$, the elongation at break value increased by $0.02 \%$, which was $0.20 \%$.

Young modulus measures the strength or elasticity of a material when stress is applied [27]. This value is obtained from the ratio of stress and strain based on the stress curve (y-axis) - strain (x-axis). The greater the young modulus value, the stiffer the material can be, and vice versa [28]. Based on the test results on the three samples, it is known that the highest modulus young value is found in the woven fiber sample with the highest ATH concentration (60 phf) of $2.83 \mathrm{GPa}$. Meanwhile, for woven fibers with a concentration of $15 \mathrm{phf}$ and $30 \mathrm{phf}$, they were $2.73 \mathrm{GPa}$ and $1.49 \mathrm{GPa}$, respectively. In this case, it means that the addition of ATH concentration causes the fiber to be inelastic/stiff. ATH has the form of pollen with waterinsoluble properties. This dense and rigid nature causes the limitation of the motion of the polymer molecules. Based on the results of the mechanical test above, ballistic testing was carried out on samples with a concentration of ATH 60 phf.

In this study, the burn test was carried out to determine the ability of the fiber to withstand a given flame. The combustion test carried out refers to the ASTM D6413 standard, wherein this test, the time of flame, burn, and length of fiber burned (coal) is analyzed by repeating each of 5 times. Fibers measuring $30 \times 5 \mathrm{~cm}$ are glued to the frame of the test equipment with a clamp. Then a flame $3 \mathrm{~cm}$ long is applied to the fibers and held for up to 12 seconds. Furthermore, 3 test parameters, such as flame, burn, and coal, are analyzed. The best results on the sample are used as core composite sandwiches. 
Based on Table 2, the sample with the best fire resistance ability at the highest concentration is the TK-3 sample (60 phf concentration), with flame, burn, and coal length times were 3,706 s, 17,648 s, and $6.3 \mathrm{~cm}$, respectively. The high concentration of ATH results in high thermal properties and fire resistance. The role of ATH in fibers with high concentrations is quite effective in inhibiting the propagation of larger (long) flames. The relatively low flame time records evidence it. The length of the intact fibers burned at this concentration $\pm 3 \mathrm{~cm}$ and left a little black mark along the $\pm 3.3 \mathrm{~cm}$. High burn resistance can be caused by a large amount of ATH filling the void in the fiber bundle. In the ATH coating process, the woven fibers are firstly immersed for $\pm 15 \mathrm{~min}$. This causes a widening of the fiber surface and an ATH filling. The retention of flame on the fiber (thermal decomposition) occurs through an endothermic process which is the basic principle of the mechanism of action of ATH. The thermal decomposition of ATH takes place at $220^{\circ} \mathrm{C}$. The decomposition process produces several water vapor $\left(3 \mathrm{H}_{2} \mathrm{O}\right)$, reducing the interaction between the fiber surface and oxygen $\left(\mathrm{O}_{2}\right)$. The aluminum $\left(\mathrm{Al}_{2} \mathrm{O}_{3}\right)$ formed acts as a surface protector for the fibers. Therefore, further spread of the fire did not occur. In general, the present work has contributed significantly to the development of material derived from natural resources.

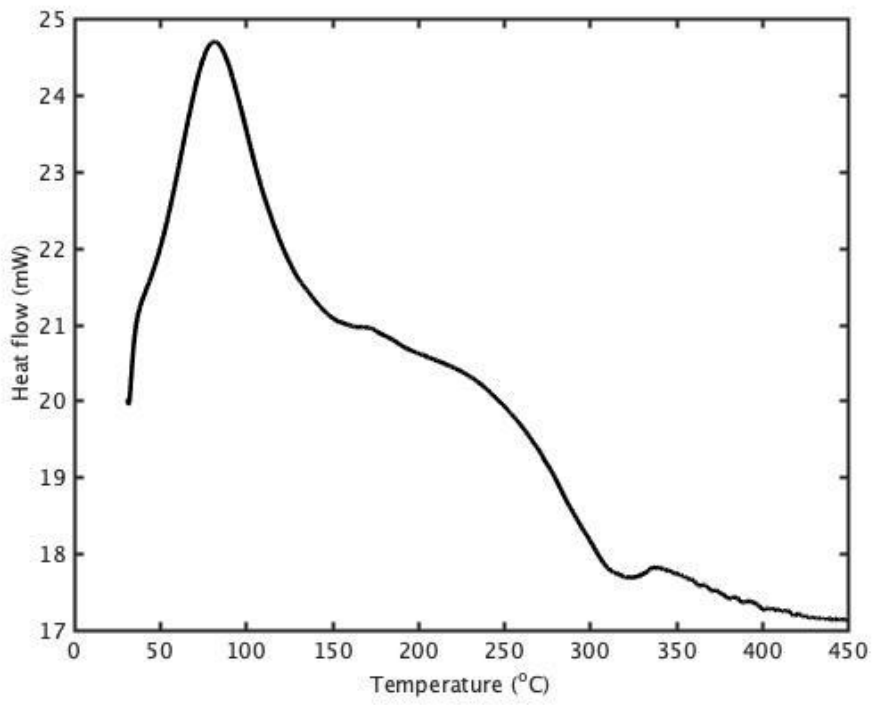

Figure 5. Thermal properties of OPEFB.

\begin{tabular}{l|l|l|l}
\multicolumn{4}{c}{ Table 1. Tensile strength of OPEFB fibers. } \\
Repetition & $\begin{array}{l}\text { Tensile Strength } \\
(\mathbf{M P a}) \text { non-woven }\end{array}$ & $\begin{array}{l}\text { Tensile Strength } \\
(\mathbf{M P a}) \text { woven }\end{array}$ & $\begin{array}{l}\text { Tensile Strength (MPa) } \\
\text { bundle fiber }\end{array}$ \\
\hline 1 & 5.45 & 80.44 & 34.11 \\
\hline 2 & 3.27 & 79.61 & 34.11 \\
\hline 3 & 6.55 & 81.27 & 25.59 \\
\hline 4 & 7.39 & 82.10 & 27.06 \\
\hline 5 & 4.73 & 78.78 & 34.11 \\
\hline Average & 5.48 & 80.44 & 30.99
\end{tabular}

Table 2. Burn test of several prepared samples.

\begin{tabular}{l|l|l|l} 
Sample & Flame $(\mathbf{s})$ & Burn $(\mathbf{s})$ & Coal $(\mathbf{c m})$ \\
\hline TK-3 & $3.706 \pm 2.31$ & $17.648 \pm 7.96$ & $6.3 \pm 1.44$ \\
\hline TK-2 & $45.626 \pm 42.81$ & $82.21 \pm 88.14$ & $9.4 \pm 4.02$ \\
\hline TK-1 & $131.53 \pm 91.76$ & $350.294 \pm 222.85$ & $23.9 \pm 5.96$ \\
\hline TK-0 & $175.146 \pm 33.20$ & $613.748 \pm 179.2$ & $30 \pm 0$
\end{tabular}

Although several synthetic materials have been established, the current trend focuses on how they can be derived from natural resources because of their hugely available in the 
environment and their performance is comparable with the synthetic materials [29-33]. Therefore, the development of materials derived from natural resources has been more popular and has been applied for various applications [34-39].

\section{Conclusions}

This study aimed to analyze the behaviors of long fibers derived from OPEFB for the potential woven and non-woven textiles production. Findings from this study exhibited that the OPEFB can potentially produce woven and non-woven textiles. The properties of OPEFB fibers were comparable with synthetics fibers that are commonly used in the textile industry.

\section{Funding}

This research was funded by the Ministry of Education and Culture and the Ministry of Research, Technology and Higher Education under contract No. 3999/IT3.L1/PN/2020.

\section{Acknowledgments}

The authors thank the IPB University and Universitas Nahdlatul Ulama Surabaya for facilitating the research work.

\section{Conflicts of Interest}

The authors declare no conflict of interest

\section{References}

1. Aisyah, H.A.; Paridah, M.T.; Sapuan, S.M.; Ilyas, R.A.; Khalina, A.; Nurazzi, N.M.; Lee, S.H.; Lee, C.H. A Comprehensive Review on Advanced Sustainable Woven Natural Fibre Polymer Composites. Polymers 2021, 13, 471, https://doi.org/10.3390/polym13030471.

2. Gholampour, A.; Ozbakkaloglu, T. A review of natural fiber composites: properties, modification and processing techniques, characterization, applications. J. Mater. Sci. 2020, 55, 829-892, https://doi.org/10.1007/s10853-019-03990-y.

3. Korzeniewska, E.; De Mey, G.; Pawlak, R.; Stempień, Z. Analysis of resistance to bending of metal electroconductive layers deposited on textile composite substrates in PVD process. Sci. Rep. 2020, 10, 8310, https://doi.org/10.1038/s41598-020-65316-2.

4. Nadzri, S.N.I.H.A.; Sultan, M.T.H.; Shah, A.U.M.; Safri, S.N.A.; Talib, A.R.A.; Jawaid, M.; Basri, A.A. A comprehensive review of coconut shell powder composites: Preparation, processing, and characterization. $J$. Thermoplast. Compos. Mater. 2020, https://doi.org/10.1177/0892705720930808.

5. Nikmatin, S.; Hermawan, B.; Irmansyah, I.; Indro, M.N.; Kueh, A.B.H.; Syafiuddin, A. Evaluation of the Performance of Helmet Prototypes Fabricated from Acrylonitrile Butadiene Styrene Composites Filled with Natural Resource. Materials 2019, 12, 34, https://doi.org/10.3390/ma12010034.

6. Nikmatin, S.; Syafiuddin, A.; Hong Kueh, A.B.; Maddu, A. Physical, thermal, and mechanical properties of polypropylene composites filled with rattan nanoparticles. J. Appl. Res. Technol. 2017, 15, 386-395, https://doi.org/10.1016/j.jart.2017.03.008.

7. Tang, P.L.; Hong, W.L.; Yue, C.S.; Harun, S. Palm oil mill effluent as the pretreatment solvent of oil palm empty fruit bunch fiber for fermentable sugars production. Bioresour. Technol. 2020, 314, 123723, https://doi.org/10.1016/j.biortech.2020.123723.

8. Solikhin, A.; Hadi, Y.S.; Massijaya, M.Y.; Nikmatin, S. Morphological and chemo-thermal changes of ovenheat treated oil palm empty fruit bunch fibers during dry disk milling. J. Indian Acad. Wood Sci. 2017, 14, 917, https://doi.org/10.1007/s13196-016-0182-6.

9. Solikhin, A.; Hadi, Y.S.; Massijaya, M.Y.; Nikmatin, S. Novel Isolation of Empty Fruit Bunch Lignocellulose Nanofibers Using Different Vibration Milling Times-Assisted Multimechanical Stages. Waste Biomass Valorization 2017, 8, 2451-2462, https://doi.org/10.1007/s12649-016-9765-0. 
10. Ng, K.H. Adoption of TiO2-photocatalysis for palm oil mill effluent (POME) treatment: Strengths, weaknesses, opportunities, threats (SWOT) and its practicality against traditional treatment in Malaysia. Chemosphere 2021, 270, 129378, https://doi.org/10.1016/j.chemosphere.2020.129378.

11. Cheng, Y.W.; Chong, C.C.; Lam, M.K.; Ayoub, M.; Cheng, C.K.; Lim, J.W.; Yusup, S.; Tang, Y.; Bai, J. Holistic process evaluation of non-conventional palm oil mill effluent (POME) treatment technologies: A conceptual and comparative review. J. Hazard. Mater. 2021, 409, 124964, https://doi.org/10.1016/j.jhazmat.2020.124964.

12. Moksin, N.S.A.; Ong, Y.P.; Ho, L.-N.; Tay, M.G. Optimization of photocatalytic fuel cells (PFCs) in the treatment of diluted palm oil mill effluent (POME). J. Water Process. Eng. 2021, 40, 101880, https://doi.org/10.1016/j.jwpe.2020.101880.

13. Lai, D.S.; Osman, A.F.; Adnan, S.A.; Ibrahim, I.; Alrashdi, A.A.; Ahmad Salimi, M.N.; Ul-Hamid, A. On the Use of OPEFB-Derived Microcrystalline Cellulose and Nano-Bentonite for Development of Thermoplastic Starch Hybrid Bio-Composites with Improved Performance. Polymers 2021, 13, 897, https://doi.org/10.3390/polym13060897.

14. Karunakaran, V.; Abd-Talib, N.; Kelly Yong, T.-L. Lignin from oil palm empty fruit bunches (EFB) under subcritical phenol conditions as a precursor for carbon fiber production. Mater. Today 2020, 31, 100-105, https://doi.org/10.1016/j.matpr.2020.01.252.

15. Ismail, F.; Othman, N.E.A.; Wahab, N.A.; Aziz, A.A. Influence of Sulphuric Acid Concentration on the Physico-Chemical Properties of Microfibrillated Cellulose from Oil Palm Empty Fruit Bunch Fibre. J. Oil Palm Res. 2020, 32, 621-629, https://doi.org/10.21894/jopr.2020.0057.

16. Abu-Thabit, N.Y.; Judeh, A.A.; Hakeem, A.S.; Ul-Hamid, A.; Umar, Y.; Ahmad, A. Isolation and characterization of microcrystalline cellulose from date seeds (Phoenix dactylifera L.). Int. J. Biol. Macromol. 2020, 155, 730-739, https://doi.org/10.1016/j.ijbiomac.2020.03.255.

17. Ramlee, N.A.; Naveen, J.; Jawaid, M. Potential of oil palm empty fruit bunch (OPEFB) and sugarcane bagasse fibers for thermal insulation application - A review. Constr Build Mater. 2021, 271, 121519, https://doi.org/10.1016/j.conbuildmat.2020.121519.

18. Zailuddin, N.L.I.; Osman, A.F.; Rahman, R. Morphology, mechanical properties, and biodegradability of allcellulose composite films from oil palm empty fruit bunch. SPE Polymers 2020, 1, 4-14, https://doi.org/10.1002/pls2.10008.

19. Lona Batista, N.; Anagnostopoulos, K.; Cocchieri Botelho, E.; Kim, H. Influence of crystallinity on interlaminar fracture toughness and impact properties of polyphenylene sulfide/carbon fiber laminates. Eng. Failure Anal. 2021, 119, 104976, https://doi.org/10.1016/j.engfailanal.2020.104976.

20. Kar Mun Amelia, C.; Yong Ng, L.; Yin Ng, C.; Mahmoudi, E.; Hanis Hayati Hairom, N.; Keat Mah, S. Polyethersulfone-cellulose composite thin film incorporated with regenerated-cellulose extracted from empty fruit bunches of elaeis guineensis. Mater. Today 2021, https://doi.org/10.1016/j.matpr.2021.01.776.

21. Wang, J.; Li, X.; Cheng, Q.; Lv, F.; Chang, C.; Zhang, L. Construction of $\beta-\mathrm{FeOOH} @$ tunicate cellulose nanocomposite hydrogels and their highly efficient photocatalytic properties. Carbohydr. Polym. 2020, 229, 115470, https://doi.org/10.1016/j.carbpol.2019.115470.

22. Zhang, L.; Li, X.; Zhang, S.; Gao, Q.; Lu, Q.; Peng, R.; Xu, P.; Shang, H.; Yuan, Y.; Zou, H. Micro-FTIR combined with curve fitting method to study cellulose crystallinity of developing cotton fibers. Anal. Bioanal. Chem. 2021, 413, 1313-1320, https://doi.org/10.1007/s00216-020-03094-6.

23. Kubovský, I.; Kačíková, D.; Kačík, F. Structural Changes of Oak Wood Main Components Caused by Thermal Modification. Polymers 2020, 12, 485, https://doi.org/10.3390/polym12020485.

24. Isroi; Ishola, M.M.; Millati, R.; Syamsiah, S.; Cahyanto, M.N.; Niklasson, C.; Taherzadeh, M.J. Structural changes of oil palm empty fruit bunch (OPEFB) after fungal and phosphoric acid pretreatment. Molecules 2012, 17, 14995-15012, https://doi.org/10.3390/molecules171214995.

25. Abdul Karim, M.H.; Mohd Shah, M.K.; Jundam, M.F.; Abdullah, S. Investigation of Tensile Properties of the Eco-Board of Hybrid Composite that Consist Of Oil Palm Empty Fruit Bunch (OPEFB) Fiber Added with Rice Husk. IOP Conf Ser Mater Sci Eng 2020, 834, 012012, https://doi.org/10.1088/1757899x/834/1/012012.

26. Djafari Petroudy, S.R., 3 - Physical and mechanical properties of natural fibers. In Advanced High Strength Natural Fibre Composites in Construction. Fan, M. and Fu, F., Eds.; Woodhead Publishing, 2017; 59-83, https://doi.org/10.1016/B978-0-08-100411-1.00003-0. 
27. Zailuddin, N.L.I.; Osman, A.F.; Rahman, R. Effect of Chemical Treatment on Tensile Properties of Oil Palm Empty Fruit Bunch (OPEFB)-based All Cellulose Composite (ACC) Films. IOP Conf Ser Mater Sci Eng 2020, 957, 012004, https://doi.org/10.1088/1757-899x/957/1/012004.

28. Serra-Parareda, F.; Tarrés, Q.; Espinach, F.X.; Vilaseca, F.; Mutjé, P.; Delgado-Aguilar, M. Influence of lignin content on the intrinsic modulus of natural fibers and on the stiffness of composite materials. Int. J. Biol. Macromol. 2020, 155, 81-90, https://doi.org/10.1016/j.ijbiomac.2020.03.160.

29. Nikmatin, S.; Syafiuddin, A.; Irwanto, D.A.Y., Properties of oil palm empty fruit bunch-filled recycled acrylonitrile butadiene styrene composites: Effect of shapes and filler loadings with random orientation. BioResources, 2016. 12, 1090-1101, https://doi.org/10.15376/biores.12.1.1090-1101.

30. Nikmatin, S.; Syafiuddin, A.; Kueh, A.B.H.; Purwanto, Y.A., Effects of nanoparticle filler on thermo-physical properties of rattan powder-filled polypropylene composites. Jur. Tek., 2015. 77, 181-187, https://doi.org/10.11113/jt.v77.6415.

31. Syafiuddin, A.; Fulazzaky, M.A.; Salmiati, S.; Kueh, A.B.H.; Fulazzaky, M.; Salim, M.R., Silver nanoparticles adsorption by the synthetic and natural adsorbent materials: an exclusive review. Nano. Env. Engg., 2020. 5, 1-18, https://doi.org/10.1007/s41204-019-0065-3.

32. Syafiuddin, A.; Salmiati, S.; Hadibarata, T.; Kueh, A.B.H.; Salim, M.R., Novel weed-extracted silver nanoparticles and their antibacterial appraisal against a rare bacterium from river and sewage treatment plan. Nanomaterials, 2018. 8, 1-17, https://doi.org/10.3390/nano8010009.

33. Syafiuddin, A.; Salmiati, S.; Hadibarata, T.; Salim, M.R.; Kueh, A.B.H.; Suhartono, S., Removal of silver nanoparticles from water environment: Experimental, mathematical formulation, and cost analysis. Water Air Soil Pollut., 2019. 230, 102-117, https://doi.org/10.1007/s11270-019-4143-8.

34. Mostafa, A.A.-F.; Elshikh, M.S.; Al-Askar, A.A.; Hadibarata, T.; Yuniarto, A.; Syafiuddin, A., Decolorization and biotransformation pathway of textile dye by Cylindrocephalum aurelium. Bioprocess Biosyst. Eng., 2019. 42, 1483-1494, https://doi.org/10.1007/s00449-019-02144-3.

35. Nurul Aini, A.; Al Farraj, D.A.; Endarko, E.; Rubiyanto, A.; Nur, H.; Al Khulaifi, M.M.; Hadibarata, T.; Syafiuddin, A., A new green method for the synthesis of silver nanoparticles and their antibacterial activities against gram-positive and gram-negative bacteria. J. Chin. Chem. Soc., 2019. 66, 705-712, https://doi.org/10.1002/jccs.201800412.

36. Syafiuddin, A.; Fulazzaky, M.A., Decolorization kinetics and mass transfer mechanisms of Remazol Brilliant Blue $\mathrm{R}$ dye mediated by different fungi. Biotechnol. Rep., 2021. 29, e00573, https://doi.org/10.1016/j.btre.2020.e00573.

37. Al Farraj, D.A.; Hadibarata, T.; Yuniarto, A.; Alkufeidy, R.M.; Alshammari, M.K.; Syafiuddin, A., Exploring the potential of halotolerant bacteria for biodegradation of polycyclic aromatic hydrocarbon. Bioprocess Biosyst. Eng., 2020. 43, 2305-2314, https://doi.org/10.1007/s00449-020-02415-4.

38. Kueh, A.B.H., Spent ground coffee-awaking the sustainability prospects. Environ. Toxicol. Manage., 2021. 1, 1-6, https://doi.org/10.33086/etm.v1i1.2016.

39. Mahmud, K.N.; Wen, T.H.; Zakaria, Z.A., Activated carbon and biochar from pineapple waste biomass for the removal of methylene blue. Environ. Toxicol. Manage., 2021. 1, 30-36, https://doi.org/10.33086/etm.v1i1.2036. 